\title{
Saint Simeon the Stylite: A Psychiatric Examination of the Life of a Fifth Century Monk
}

Iracema Leroi M.D.

Dalhousie University, Halifax, Nova Scotia

Joseph B. A. Meagher M.D., M.R.C. (Psych) FRCPC

Dalhousei University, Halifax, Nova Scotia; Nova Scotia Hospital, Dartmouth, Nova Scotia

Follow this and additional works at: https://jdc.jefferson.edu/jeffjpsychiatry

Part of the Psychiatry Commons

Let us know how access to this document benefits you

\section{Recommended Citation}

Leroi, Iracema M.D. and Meagher, Joseph B. A. M.D., M.R.C. (Psych) FRCPC (1999) "Saint Simeon the Stylite: A Psychiatric Examination of the Life of a Fifth Century Monk," Jefferson Journal of Psychiatry. Vol. 14 : Iss. 2 , Article 6.

DOI: https://doi.org/10.29046/JJP.014.2.003

Available at: https://jdc.jefferson.edu/jeffjpsychiatry/vol14/iss2/6

This Article is brought to you for free and open access by the Jefferson Digital Commons. The Jefferson Digital Commons is a service of Thomas Jefferson University's Center for Teaching and Learning (CTL). The Commons is a showcase for Jefferson books and journals, peer-reviewed scholarly publications, unique historical collections from the University archives, and teaching tools. The Jefferson Digital Commons allows researchers and interested readers anywhere in the world to learn about and keep up to date with Jefferson scholarship. This article has been accepted for inclusion in Jefferson Journal of Psychiatry by an authorized administrator of the Jefferson Digital Commons. For more information, please contact: JeffersonDigitalCommons@jefferson.edu. 


\title{
Saint Simeon the Stylite: A Psychiatric Examination of the Life of a Fifth Century Monk
}

\author{
Iracema Leroi, M.D.* \\ and Joseph B.A. Meagher, M.D., M.R.C. (Psych)
}

\begin{abstract}
Religion is now the focus of more attention in psychiatry. This paper examines the life of the fifth century monk, Simeon the Stylite, from a contemporary psychiatric perspective. Such a retrospective examination presents difficulties with regard to the diagnosis of possible psychotic phenomena. A further problem is trying to distinguish between a religious and a psychiatric interpretation of particular experiences.

The authors outline the life of Simeon and some contemporary opinions. They agree with Kroll and deGanck that great caution is needed in the psychiatric interpretation and examination of an historical or religious life. This paper details some of these difficulties to help determine whether an understanding derived from modern psychiatry is relevant to a different era.
\end{abstract}

\section{INTRODUCTION}

Religion is now the focus of considerable attention in psychiatry $(1,2)$. The purpose of this paper is to examine the life of an historical religious figure from the perspective of psychiatry. The person whose life we have decided to examine, the fifth century monk, Simeon the Stylite, is important to the history of religion. We compared our current, secular view with the views of the early Christian Church and determined whether an understanding derived from modern psychiatry is relevant to a different era.

As Meissner (3) has pointed out, the psychiatrist cannot judge the validity or truth of the content of a religious belief. However, the psychiatrist can judge if someone is mentally ill and if that illness might influence the content of their beliefs in general. This examination highlights two aspects of the process of psychiatric examination of religious experience: first, that religious experience might be inter-

Iracema Leroi, MD*. Resident in Psychiatry, Dalhousie University, Halifax, Nova Scotia, Canada.

Joseph B.A. Meagher, MD, MRC(Psych). Consultant Psychiatrist, Bantry General Hospital, Bantry, Co. Cork, Ireland.

*Address for correspondence: Iracema Leroi, MD, Dept. of Psychiatry, Dalhousie University, 4th floor, Abbie Lane Bldg, Queen Elizabeth II Health Sciences Centre, Halifax, NS, B3H-3G2, (H) 902-429-1256, (W) 902-473-2222 pager 2407, ileroi@is2.dal.ca 
twined with psychiatric experience; and second, that there are numerous problems inherent in the process of medicalization of the experiences and behaviour of an historical figure.

Saints and sainthood have played a crucial role in the Christian Church for many centuries. One of the important aspects of saintliness, as pointed out by William James (4), is that saints are "the authors, the auctores, increasers, of goodness." They represent an ideal of perfection for many people. The lives of the saints, including their lives outside any particular religious experience, are studied as models for living.

\section{HISTORICAL BACKGROUND}

The life of St. Simeon Stylites was recorded by Theodoret, who was one of Simeon's contemporaries. Theodoret is the principal source of information on Simeon. He described Simeon has having lived from about $390 \mathrm{AD}$ to $459 \mathrm{AD}$ in what is today called Syria. Simeon's life and experiences have been regularly reviewed in the historical literature (5). However, we are not aware of any review of his life in the medical literature up to now.

Simeon was one of the famed pillar saints who attempted to express Godliness by living a life of austerity far removed from society. This usually involved living on top of mounds or pillars (6). The Greek for pillar is stylos, from which the word "stylites" comes. This tradition of isolation and austerity continues in both Eastern Orthodox and some Western Christian traditions.

In recent Christian tradition, the criteria for sainthood are strict. However, in the early centuries of Church history, these criteria were broader. Although Simeon Stylites would probably not be seen as a saint if he lived today, he does remain in the Canon of Saints in the Roman Catholic calendar. His feast day is on the fifth of January. The life of this saint is of particular importance to theologians as he was instrumental (through the action of his admirer, the Emperor, at church councils in the fifth century) in resolving the contending theological perspectives by the Church's decision to describe the Dual Nature of Christ. Thus, although he is not as well known as other saints, it is worthwhile examining his life.

\section{CASE HISTORY}

Simeon was the son of poor shepherds who lived in Cicilia, on the border of Syria. At the age of thirteen, he heard the beatitudes read in a nearby church and was profoundly moved. He subsequently fell prostrate to the ground and beseeched God to lead him to happiness and perfection. He had a complex vision of himself being commanded to dig a deep pit in which he had to house a tall superstructure of some sort. When he eventually arose from the ground he went to a local monastery where he pleaded to be taken in as a common servant. They eventually agreed and he subsequently spent many years living in the monastery with extreme asceticism and constant bodily mortifications. 
Simeon was repeatedly cautioned by his superiors to moderate his austere behaviour. Eventually, he was dismissed from the monastery after he was found to have hidden a rope under his tunic. The rope was tied around his waist and was so tight that it had eaten into his flesh, causing a foul stench. His actions were seen to be a "prejudice of uniformity in monastic discipline" (7). From the descriptions of Simeon's life, it seems that the monks felt a responsibility to care for him even though he had been forced to leave the monastery. For example, they provided him with bread and water during his self-imposed fasts.

After leaving the monastery, Simeon retired to an hermitage where he is reported to have spent the next forty days of Lent in total abstinence, neither eating nor drinking. Despite being nearly dead at the end of the forty days, he repeated this Lenten fast for the next twenty-six years. After three years in this hermitage, he moved to the top of a mountain where he built himself a stone enclosure without a roof. He stayed in this enclosure, fully exposed to the elements. By this time, admirers from the local population thronged to the mountain in order to receive his benediction. In $423 \mathrm{AD}$, in order to get away from the crowds, he erected a tall pillar upon which he lived for the next 27 years. At first, this rather unusual behaviour was censured by the local bishops and abbots as being a mark of vanity or extravagance. However, they later relented and allowed him to pursue what he felt was his vocation from God.

As time passed, Simeon became a local attraction and crowds came to see him and hear him preach. He increased the height of his pillar and eventually it stood 36 cubits high. The diameter of the top of the pillar was more than about a meter. His bodily needs were cared for by the monks who brought him food and took away whatever he wished. The monks also ensured that he was not disturbed by the visitors by erecting a barrier around the pillar. Eventually, he gained a large following and his advice was sought by the famous. By the time of his death, he was already regarded as a saint by popular acclamation. When he died, his body was carried in great procession to Antioch.

In reviewing his life, we see evidence of a religious experience combined with what we would now consider to be signs of psychopathology. Of equal interest, we see a discrepancy between the way the established Church at the time viewed his behaviour and experiences and the way his following regarded him. His followers included many notables such as the Kings of Persia and the Roman Emperor.

\section{EXAMINATION OF UNUSUAL EXPERIENCES}

In looking back on this rather unusual life, we examined the accounts to see whether we could discern any recognizable patterns of a psychiatric illness. We have divided our summary of his experiences into those components which were observed by others and those he reported himself or which we can infer that were reported by him. 


\section{1) Descriptions of behaviour reported by others:}

a) An abrupt and total withdrawal from society at a very young age. Throughout his life Simeon continued to shun the company of others.

b) Profound self-mutilation and neglect. He had serious foot ulcers which he ignored to the point that they were infested with maggots. There are frequent descriptions of the foul smell he gave off, which was striking even in the fifth century. He also had the need to mortify his flesh to such an extent that he was expelled from the monastery. He went for long periods without eating or drinking.

c) Repeated periods of prolonged motor immobility. It is recorded that he lay prostrate and immobile for several days on at least two occasions.

d) Bizarre and idiosyncratic choice of monastic life-style. He lived on top of a pillar for many years. The top of the pillar was so small that he did not even have space to lie down.

e) Repeated prophetic exhortations. From the descriptions given, it is not always possible to know if Simeon's own voice was heard by the crowd or if his words were relayed by someone else. In either case, he seems to have been preoccupied by certain themes in his preaching.

f) Repetitive, symbolic actions. One contemporary observer reported that he bowed on his pillar 1244 times in one day.

g) Excessive strivings toward purity and perfection. He would not tolerate any woman to come in close proximity of his pillar. Although this is at variance with the Western understanding of relationships, this tradition continues today among some Eastern Orthodox groups and may not necessarily reflect psychopathology.

\section{2) Descriptions of experiences described by Simeon:}

a) Visual imagery. This imagery had a detailed content of a symbolic and prophetic nature. It is unclear whether this was a vivid dream or a true hallucination. Simeon later acted on this vision by building the pillar, the tall superstructure whose foundation he had seen himself digging in his vision.

b) Hallucinations. He may have experienced auditory hallucinations of a command nature. During his vision, he was commanded to dig a deep pit. Whenever he stopped for breath, he was commanded to continue.

c) Delusional perception. After hearing a sermon on the beatitudes, he had an overwhelming sense of urgency to change his life and pursue an alternative course. He did indeed change his life and remained committed to that change until his death.

\section{DISCUSSION}

Without the normal tools of investigation, any attempt at diagnosis in Simeon's case should be tentative. However, some of the facts of his life are not in dispute and these can help to rule out some diagnostic possibilities. It seems unlikely that Simeon suffered from an organic condition which might have lead to deterioration in his 
behaviour. His comparatively long life, sixty nine years, implies that his physical health was relatively robust. There are no descriptions of grand mal type seizures, although the possibility of an epiletic focus cannot be ruled out.

It is possible that Simeon suffered from a prolonged psychotic illness, for example a schizophrenia-like psychosis. The above descriptions of his behaviour may suggest intermittent catatonic states with episodes of intense spiritual preoccupation with transcendent matters. Even if Simeon did not have a schizophrenic illness in the way we know today, it might be that Simeon had a psychotic episode, or episodes, which so transformed his view of the world as to change his relationship with it thereafter. There are no records of the exact words he used in his sermons. Whatever he said, it seems to have struck a cord with his listeners. That being the case, we might suspect that Simeon did not have overt thought form disorganisation. His opinion was sought by influential people, a condition which might mean that they, at least, regarded his words as wise and not the ramblings of a madman. So, even if Simeon had psychotic episodes, it is not certain that he had schizophrenia.

Mood disorders have long been of interest to historians of religion $(2,3,4)$. The Book of Job contains one of the great descriptions of the interplay of mood and religious experience. Unquenchable guilt can be a driving force in the need to obtain a more profound forgiveness $(3,4)$. In Simeon's case, because of the unusual nature of his circumstances, it is difficult to ascertain to what extent, if any, his behaviour was the result of a mood disorder. Some aspects of his life are compatible with a mood disorder, for example, the isolation, fasting and self-denial, but these might be better explained in another context.

Simeon's behaviour appears neurotic to us, particularly his repetitive movements which might indicate some form of ritualized undoing. It is important to note that his behaviours also appeared odd to contemporaries, although they interpreted them differently. Among anxiety disorders, obsessive-compulsive disorder fits best with Simeon's coping style. A certain amount of obsessionality would have been required for him to survive in the circumstances in which he lived.

An alternative diagnosis is schizotypal personality disorder. This latter diagnosis must be considered with caution as, according to DSM IV, the presentation must be evaluated only in the context of the individual's particular cultural surroundings (8). Simeon's repetitive symbolic actions and prophetic exhortations as well as extreme bodily mortifications, can be viewed simultaneously as illness or saintliness. We see his superiors reprimanding him for the excess of his behaviour. In contrast, we see thousands of people from all over the Middle and Near East reported as being "converted by his miracles and discourses, which they crowded to hear. Princes and queens of the Arabians came to receive his blessing. Varanes V, King of Persia, though a cruel persecutor, respected him" (7).

Other features which might indicate pathology to us, for example his determination to live apart from women, are better understood in the context of religious patterns of the day. These patterns applied to both men and women, and were by no means unique to Simeon.

It might also be argued that Simeon was going through a religious conversion 
experience. Certainly, this is how some contemporaries saw it. James (4) points out that the experience of religious conversion is common and often follows a pattern. The subject is usually guilt-ridden, self-doubting, or in some sort of interpersonal conflict and finds comfort from his torments in religion which then obviates his guilt. It is a process not unlike that described in the transition from delusional mood to delusional perception in psychosis. Certainly, the young Simeon had such a sudden transformation. However, we have no evidence that he experienced any self-doubt, guilt or interpersonal conflict of any sort prior to this experience. The intensity of the experience, which resulted in his lying prostrate for several days, suggests instead a psychotic experience with catatonia and mutism. As Schneider (9) points out, a delusional perception occurs "when some abnormal significance, usually with selfreference is attached to a genuine perception without any comprehensible, rational, or emotional justification. The significance is always of a special kind, it almost always carries great import, it is urgent and personal, a sign or message from another world ...".

As a result of our lack of more detailed accounts of his life and the obvious impossibility of a standard psychiatric interview, any specific diagnosis is unfeasible and general diagnoses are purely speculative. It is possible for someone to be mentally well but eccentric. However, there are limits to eccentricity and those are usually apparent to contemporaries. Even if this is not the case, we would not expect the eccentricities to seriously damage the individual concerned. We can say that Simeon was psychotic given the standard of our own time, but this may just reflect a bias against the behaviours and beliefs of previous eras. So, our first question is, how far are our opinions backed by those who had first hand experience of him?

The opinion of Simeon at the time was divided. Certainly he had a strong popular following, but those who knew him best were in the Church. It is from the writings of these church supporters that we have an account of his life (10). They had the objectives of describing hs life as holy and justifying the eccentricities of his behaviour. There does not seem to have been any question that Simeon was an ordinary person. For at least some of his contemporaries the experiences which we regard as psychotic were then regarded as being an unusual manifestation of God's working in the life of a man. Nevertheless, even then there was some doubt as to the extent of God's influence over his beliefs. In other words, we cannot say that contemporaries, at least those who write about him, regarded him as mentally ill but they certainly did see him as bizarre and special. For example, we have cited Simeon's visions as possible signs of mental illness. This was not how it was viewed in the fifth century. Visions were a legitimate part of the religious experience. We have to be careful not to make a conclusion which would transform a "vision," meaning an experience of religious imagination, into a visual hallucination, a symptom of mental illness. Visions alone do not make saints mad.

Other aspects of Simeon's life which may appear strange to us were part of what might be expected of a deeply religious person. Striking features of Simeon's experience were his extreme isolation and the almost total denial of the body, manifest by a lack of cleanliness and the ignoring of bodily wounds. However, these 
are characteristics of monastic life in the early middle ages. The role of what was private versus that which was public was very different in times before our own. Silence and cleanliness in the life on the monk have been examined by Georges Duby in the "History of Private Life." There it can be seen that the Rule of Saint Benedict laid down instructions on the stages of silence. Silence was seen as a means to attain greater communication with God. Duby states, "But it was understood that there was a higher degree of perfection to be achieved in solitude, that extreme form of flight from the world and the flesh which the monk was exhorted to undertake. The purpose of the Rule was to establish conditions conducive to taking the first steps toward that ideal state. In fact, the rule circumscribed not so much space as time, isolating the individual in a material and physical sense so that he would be free to concentrate on himself. The Rule of Silence, the experience of retirement and seclusion, broke communication between the individual and the group; this was a privation, but it was also a means of spiritual ascension" (11). The body itself was to be seen "cautiously and with suspicion-for the body, like woman, is temptation; it incites desire in oneself and others. The most informative sources suggest a strong tendency to fear the body, to neglect it, and even, in the more extreme forms of asceticism, to abandon it to vermin (but the texts are of course colored by the ideology of the Church, the extremist views of professional moralists)" (12).

Butler (7) makes the comment that Simeon's life was an example to be admired rather than imitated. That seems to have been the Church's attitude at the time and after. Simeon's abbots had a difficult decision to make with regard to his eccentric life. This was because he was a monk and therefore obliged to follow the rules of the order. The rules were based on the need to bring a monk closer to God. They were also an attempt to find a reasonable modus vivendi through which this might be done. Simeon's main fault in the eyes of his fellow monks was a lack of moderation in keeping the rules, rather than a disregard for them. A similar disregard for the order's strictures of self-mortification was seen in the life of Beatrice of Nazareth. Kroll and DeGanck (13) suggest that her extremes of behaviour were either part of her struggle to achieve spiritual perfection, a paradigm of the struggle between the individuality of the mystic and the constraints of an ecclesiastical structure, or that she derived secondary gain by having others take care of her. As with Beatrice, Simeon's main fault in the eyes of his fellow monks was a lack of moderation, rather than a disregard for them. As Simeon aged and his eccentric life became more accepted, his lack of moderation was considered in a more favorable light.

The second problem we face is the validity of interpreting historical lives from our current psychiatric perspective. As pointed out by Kroll and deGanck (13), one must tread cautiously in attempting to undertake psychiatric diagnoses of historical figures, particularly if that figure lived in an historical and cultural context different to our own. Kroll and deGanck argue that neither the purely psychiatric nor the purely religious approach is a satisfactory method of explaining a particular set of behaviours. The latter view is not always compatible with current understandings of brain and behaviour relationships, whereas the former is exclusively reductionistic and fails to take the cultural context and contemporary norms into account. In this 
examination, we have attempted to outline both contemporary religious and current psychiatric viewpoints in the life of this unusual saint.

From the historical point of view, there are also many methodological problems. The few accounts of the life of St. Simeon leave many questions with regard to the actual nature of his behaviour and experiences. Historical accounts may be exaggerated by biographers in order to highlight the unusual aspects of their lives which made them notorious in the first place. Further problems arise in that the early accounts were written for a religious audience and in a theological context; applying the medical model to such accounts may be inherently flawed (13).

Is it possible then that both explanations, religious and psychiatric, might contribute to our understanding of this unusual saint? It is possible that St. Simeon demonstrated behaviour which encompassed both psychiatric phenomenology as well as the religious fervor of a visionary and holy man.

Indeed, even if we accept the possibility of a psychiatric diagnosis, this does not detract from his importance as a religious figure who made pronouncements that have theological consequences even today.

\section{REFERENCES}

1. Crossley D: Religious experience within mental illness; opening the door on research. British J Psychiatry 1995; 284-286.

2. Larson DB: Systematic analysis of research on religious variables in four major psychiatric journals 1978-1982. Am J Psychiatry 1986; 143:3, 329-334.

3. Meissner WW: The phenomenology of religious psychopathology. Bull of the Menninger Foundation 1991; 55: 281-298.

4. James W: Varieties of religious experience. 1902 The Riverside Press.

5. Searight S: St Simeon Stylites. History Today 1978 April 28; 242-248.

6. McBrien RP (ed): Encyclopedia of Catholicism. 1995 Harper Collins 1226.

7. Butler A: The lives of the Fathers, Martyrs and other principal saints. 1883; London and Dublin J S Virtue and Co ltd.

8. Bourguignon E: Cross-cultural perspectives on the religious uses of altered states of consciousness. Religious Movements in Contemporary America. (ed Zaretsky II and Leone MP,:) 1974; 228-243. Princeton; Princeton University Press.

9. Schneider K: Clinical psychopathology. (translated by M Hamilton) 1959 New York Grune and Stratton.

10. Doran R: The lives of Simeon Stylites. (translation) 1992 London Cistercian Publications.

11. Duby G (ed): A History of Private Life, 1995 ed. Harvard University Press; Vol II 514.

12. Duby G (ed): A History of Private Life, 1995 Harvard University Press; Vol II 524.

13. Kroll J and DeGanck R: The adolescence of a thirteenth-century visionary nun. Psychological Medicine 1986; 16: 745-756. 